\title{
Renin-Angiotensin System (RAS) Expressions in Myeloid Leukemic Cell Lines
}

\author{
Burak UZ' , Suzin C. TATONYAN ${ }^{2}$, Muge SAYITOGLU ${ }^{2}$, Yucel ERBILGIN ${ }^{2}$, Ozden HATIRNAZ NG ${ }^{2}$, \\ Yahya BUYUKASIK' ${ }^{1}$, Salih AKSU1, Nilgun SAYINALP', Hakan GOKER ${ }^{1}$, Osman I. OZCEBE ${ }^{1}$, \\ Ugur OZBEK ${ }^{2}$, Ibrahim C. HAZNEDAROGLU ${ }^{1}$ \\ ${ }^{1}$ Hacettepe University Department of Internal Medicine, Hematology Unit, Ankara \\ ${ }^{2}$ Istanbul University Institute for Experimental Medicine Research, Genetics Department, Istanbul, TURKEY
}

\begin{abstract}
The aim of this study is to search critical renin-angiotensin system (RAS) elements in myeloid leukemic cell lines. Human acute myeloid leukemia (AML) cell lines, KG-1 and HL-60, were cultured. We searched for the gene expression of the major RAS components in $\mathrm{KG}-1$ and $\mathrm{HL}-60$ cell lines by quantitative real-time polymerase chain reaction analysis (qRT-PCR). Angiotensin-converting enzyme I (ACE I) and ACE II mRNA expressions were detected in KG-1 AML cell line. Relative expression of ACE I was higher than ACE II expression in this myeloid leukemic cells. Likewise, RENIN, angiotensinogen (ANGTS), and ACE I mRNA expressions were detected in HL-60 promyelocytic cell line. Relative RENIN expression was the highest, whereas ACE I expression was the lowest in $\mathrm{HL}-$ 60 neoplastic myeloid cells. These findings indicate that there is a biologically active local RAS in the hematopoietic system in normal and pathological states.
\end{abstract}

Keywords: Renin-angiotensin system, KG-1 AML cell line, HL-60 promyelocytic cell line, mRNA expressions

\section{ÖZET}

Miyeloid Lösemik Hücre Dizilerinde Renin-Anjiyotensin Sistem (RAS) Ekspresyonları

Bu çalışmanın amacı miyeloid lösemik hücre dizilerinde kritik renin-anjiyotensin sistemi (RAS) elemanlarının varlığını araştırmaktır. İnsan akut miyeloid lösemi (AML) hücre dizileri, KG-1 ve HL-60, kültüre edildi. Temel RAS elemanlarının KG-1 ve HL-60 hücre dizilerindeki gen ekspresyon düzeyleri kuantitatif gerçek zamanlı polimeraz zincir reaksiyonu (qRT-PCR) ile araştııldı. KG-1 AML hücre dizisinde anjiyotensin-dönüştürücü enzim I (ACE I) ve ACE || mRNA ekspresyonları saptandl; ACE I rölatif ekspresyonu, ACE I| ekspresyonundan yüksek idi. Benzer şekilde, HL-60 promyelositik hücre dizisinde RENIN, anjiyotensinojen (ANGTS) ve ACE I mRNA ekspresyonları saptandı. HL-60 neoplastik miyeloid hücrelerinde rölatif RENIN ekspresyonu en yüksek iken, ACE I ekspresyonu en düşük düzeyde bulundu. Bu bulgular hematopoetik sistemde normal ve patolojik durumlarda biyolojik aktif lokal bir RAS varlığını göstermektedir.

Anahtar Kelimeler: Renin-anjiyotensin sistemi, KG-1 AML hücre dizisi, HL-60 promiyelositik hücre dizisi, mRNA ekspresyonları 


\section{INTRODUCTION}

There is a local renin-angiotensin system (RAS) in the hematopoietic bone marrow (BM).$^{1-3}$ All of the RAS molecules such as renin, angiotensinogen (ANGTS), angiotensin receptors (AT1R and AT2R), AcSDKP and angiotensin-converting enzyme (ACE) are present in the BM microenvironment and cellular compartment. ${ }^{2,45}$ Local BM RAS acts in an autocrine, paracrine, and intracrine fashion affecting all of the cellular lineages. Local hematopoietic RAS is effective in the primitive embryonic hematopoiesis ${ }^{6.7}$ and neoplastic blood production. ${ }^{2,8-}$ 11

Local BM RAS modulates myelopoiesis. Leukocytes express the angiotensinogen gene, synthesizing and releasing angiotensinogen with the capability to generate angiotensin (Ang)..$^{12}$ Prominent myelopoietic abnormalities characterized by increased BM myeloblasts and myeloid cells, as well as extramedullary myelopoiesis are present in the ACE (CD143)-knockout mice. ${ }^{13}$ Moreover, there are preliminary evidences that local BM RAS may be important in the pathobiology of myeloid leukemias. ${ }^{9,14-16}$ Casares et al.${ }^{17}$ demonstrated that some myeloid blasts express renin, but normal BM does not display this expression. They observed renin expression in cells from acute myeloid leukemia (AML), chronic myeloid leukemia (CML) and acute lymphoid leukemia (ALL). The highest frequency was observed in the AML patients (47.2\% of the cases). Renin expression was disappeared during the complete remission of AML. ${ }^{17,18}$

The aim of the present study is to search critical RAS elements in myeloid leukemic cell lines. For this aim, KG-1 AML and HL-60 promyelocytic cell lines were analyzed via the quantitative real-time polymerase chain reaction analysis (qRT-PCR). Elucidation of the status of the local RAS molecules in the leukemic hematopoiesis represents a clinically relevant basic research area for better understanding the biology of the diseases.

\section{MATERIALS AND METHODS}

\section{Cell Culture, RNA Isolation and cDNA Synthesis}

Human AML cell lines KG-1 (erythroleukemia cell line, spontaneously differentiate to granulocyte and macrophage like cells) and HL-60 (promyelocytic cell line) were cultured in RPMI 1640 (Invitrogen Life Technologies, USA), supplemented with $10 \%$ FCS, penicillin $(50 \mathrm{U} / \mathrm{mL})$, streptomycin (50 $\mathrm{mg} / \mathrm{mL}$; both Invitrogen Life Sciences, USA).

Total ribonucleic acid (RNA) was isolated according to the manufacturer's instructions (Qiagen, Germany). RNA quality was measured by spectrophotometer (ND-1000, Nanodrop Technologies, Inc., USA), and one microgram of total RNA was used. Random primers ( $20 \mu \mathrm{M}$, Roche Diagnostics, Germany), dNTP set $10 \mathrm{mM}$ (Fermentase UAB, Lithuania), RiboLock Rnase Inhibitor (20 U/ $\mu$, Fermentas) and Moloney murine leukemia virus (MMLV) reverse transcriptase (200 U/ $\mu 1$, Fermentas) were used for cDNA synthesis. cDNA samples were stored at $-20^{\circ} \mathrm{C}$.

\section{Quantitative real-time polymerase chain reacti- on analysis (qRT-PCR)}

We searched for the gene expression of the major RAS components (ACE I, ACE II, RENIN and ANGTS) in KG-1 and HL-60 cell lines by qRTPCR. Previously designed primer-probes were used. ${ }^{.1}$ mRNA levels were normalized to CYPA and B-ACT genes. qRT-PCR analyses for ACE, RENIN and ANGTS gene expressions were performed using a LightCycler 480 instrument (Roche Diagnostics). Real-time amplification was performed with a final reaction mixture of $20 \mu \mathrm{l}$ containing 5 $\mu \mathrm{M}$ of each primer, $0.5 \mu \mathrm{M}$ of each probe and LightCycler 480 Probe Master Mix and $100 \mathrm{ng} / \mu \mathrm{l}$ of cDNA. Each sample was studied in duplicate and all runs were repeated twice. The PCR protocol was as follows: initial denaturation at $95^{\circ} \mathrm{C}$ for 7 min, amplification segment at $5 \mathrm{sec}$ at $95^{\circ} \mathrm{C}, 10 \mathrm{sec}$ at $60^{\circ} \mathrm{C}$, and $10 \mathrm{sec}$ at $72^{\circ} \mathrm{C}$ for 45 cycles. The $2-\mathrm{Ct}$ method was used to calculate relative expression levels determined from the qRT-PCR experiments. ${ }^{19}$ Differences between two groups were assessed by the Mann-Whitney U test. A p value of $\leq .05$ was considered as statistically significant.

\section{RESULTS}

KG-1 AML cell line and relative expressions of the RAS components

ACE I and ACE II mRNA expressions were detected. Relative expression of ACE I was higher than ACE II expression $(\mathrm{p}<0.05)$ (Figure 1). 


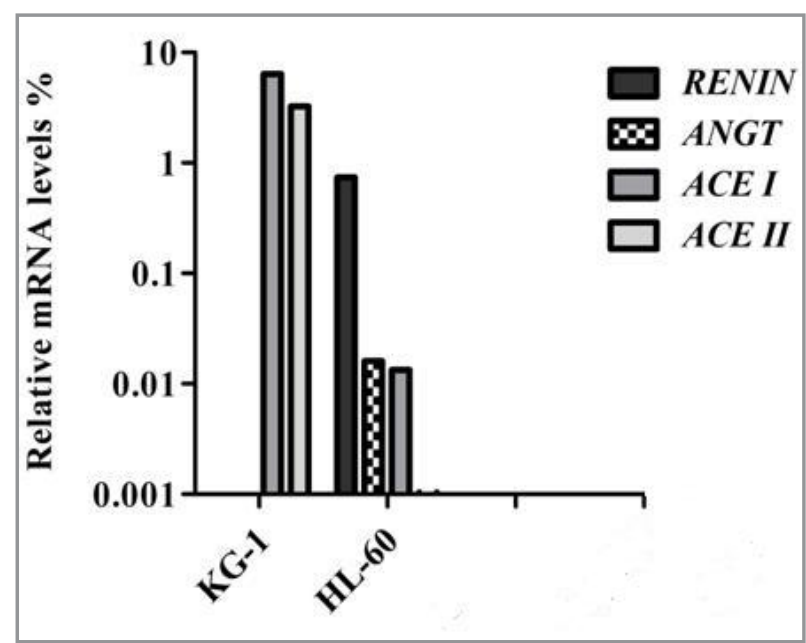

Figure 1. Relative mRNA levels (\%) of the RAS components in KG-1 and HL-60 cells.

\section{HL-60 promyelocytic cell line and relative exp- ressions of the RAS components}

RENIN, ANGTS, and ACE I mRNA expressions were detected. Relative RENIN expression was the highest, whereas ACE I expression was the lowest $(p<0.05)$ (Figure 1).

\section{DISCUSSION}

In this study, ACE I and ACE II mRNA expressions were detected in KG-1 AML cell line. Relative expression of ACE I was higher than ACE II expression in this myeloid leukemic cells. Likewise, RENIN, ANGTS, and ACE I mRNA expressions were detected in HL-60 promyelocytic cell line. Relative RENIN expression was the highest, whereas ACE I expression was the lowest in HL-60 neoplastic myeloid cells (Figure 1). These findings support our original hypothesis that there is a biologically active local RAS in the hematopoietic system in normal and pathological states. ${ }^{13,20}$

ACE existence in human primitive lympho-hematopoietic cells, embryonic, fetal and adult hematopoietic tissues cast attention to the effects of RAS on neoplastic tissues. ${ }^{6.7}$ Immunohistochemical studies showed the possible role of ACE/RAS in BM by evaluating $\mathrm{ACE}$ expression in normal $\mathrm{BM}$, several myeloproliferative disorders and myelodysplasia. ${ }^{21} \mathrm{ACE}$ and $\mathrm{p} 53$ expressions were detected in the
CD34+cells in the patients with acute leukemia during and after induction chemotherapy. ${ }^{22}$ In vitro incubation of AML cells with an ACE inhibitor decreased the growth and colony-forming ability of AML cells in a dose-dependent manner. Adding of Ang-II peptide to AML cells partially rescued their colony-forming ability. ${ }^{23}$ Over-expression of ACE (CD 143) surface antigen in leukemic myeloid blast cells have been detected by flow cytometric analyses. Moreover, a positive correlation has been found between the ACE and BM blast count. ${ }^{15}$ Our preliminary results regarding the ACE expressions in myeloid leukemic cells represent another clue for the actions of ACE in myeloid leukemogenesis.

RENIN expression was the highest in HL-60 myeloid leukemic cells in our study. The associations between renin and AML have previously been searched. The relevance of the renin expression as an aberrant leukemic marker in acute leukemia has been proposed by real-time PCR analyses. Renin-like enzyme activity converting ANGTS to Ang-I had been detected in leukemic blast cells. ${ }^{24,25}$ Specific immunoreactive renin-like peptide of $47 \mathrm{kDa}$ was isolated from AML blast cells. ${ }^{24,25}$ Renin is expressed in some myeloid human leukemia cell lines such as K562, KU812 and MEG-01., ${ }^{918,26}$ Renin system is present in the K562 leukemic cell line in vitro model. Multipotential, hematopoietic malignant K562 leukemic blast cells also exhibited significant expressions of the renin, ANGTS and ACE. ${ }^{9}$ When K562 cells were treated with inducers of growth inhibition and/or differentiation, renin expression did not disappear, indicating that renin expression is associated with a blastic phenotype rather than with cell proliferation. ${ }^{17}$ Inigo and coworkers analysed 76 samples from patients with AML. Thirty-one patients $(41 \%)$ were positive for renin gene expression at diagnosis. All renin-positive patients at diagnosis showed no expression during complete remission (CR), but expression recurred in those experiencing relapse and persisted when the disease was refractory to treatment. ${ }^{18}$ The chimeric protein NUP98-HOXA9, is a prototype of several NUP98 fusions that occur in AML and myelodysplastic syndromes. NUP98-HOXA9 affects the differentiation, proliferation, and gene expression of the primary human CD34+ hematopoietic cells. NUP98HOXA9 can increase the numbers of erythroid precursors and impaired both myeloid and erythroid 
differentiation. Increased renin gene activity was detected during the NUP98-HOXA9 enhanced blast formation..$^{27,28}$ Increased RENIN expression in HL-60 myeloid leukemic cells in our study supports the place of this RAS peptide in the leukemogenesis.

RAS affects numerous biological events that are important for the formation and function of blood cells. Apoptosis, cellular proliferation, intracellular signaling, mobilization, angiogenesis, fibrosis within the cytokine network, and many other essential pathobiological events are affected by the critical RAS molecules. ${ }^{2}$ Neoplastic malignant blood cells are derived from the leukemic stem cells within a complex series of pathological proliferative steps. Hematological clonal neoplastic disorders are characterized by the excessive production of malign cells as well as the disordered apoptosis, impaired differentiation, pathological signaling, and cancer angiogenesis. Inigo and coworkers ${ }^{26}$ investigated the effect of captopril, trandolapril and losartan on K562 leukemic cell line and K562 transfected with c-myc, bcl-x and bcl-2 (KmycB, Kbclx and Kbcl2 respectively). ACE inhibitors and losartan inhibited cell growth, decreased c-myc expression and increased apoptosis in their study. ${ }^{26}$ Since most of the cellular effects of the local RAS are in an autocrine, paracrine and intracrine fashion, future drugs intended to modulate local RAS functions shall be prepared to have local targeted actions in the tissue microenvironment such as inside BM. Therefore the underlying mechanisms and clinicopathological associations of RAS in myeloid leukemic disorders should be further evaluated not only for academical purposes but also better understanding the biology and future management of the leukemic patients.

\section{REFERENCES}

1. Haznedaroglu IC. A local renin-angiotensin system in the bone marrow still awaits its Christopher Columbus. Exp Hematol 26: 279, 1998.

2. Haznedaroglu IC, Beyazit Y. Local bone marrow reninangiotensin system in primitive, definitive and neoplastic haematopoiesis. Clin Sci (Lond) 124: 307-323, 2013.

3. Haznedaroglu IC, Tuncer S, Gursoy M. A local reninangiotensin system in the bone marrow. Med Hypotheses 46: 507-510, 1996.
4. Haznedaroglu IC, Beyazit Y. Pathobiological aspects of the local bone marrow renin-angiotensin system: a review. J Renin Angiotensin Aldosterone Syst 11: 205213, 2010

5. Haznedaroglu IC, Ozturk MA. Towards the understanding of the local hematopoietic bone marrow renin-angiotensin system. Int J Biochem Cell Biol 35: 867-880, 2003.

6. Sinka L, Biasch K, Khazaal I, et al. Angiotensin-converting enzyme (CD143) specifies emerging lymphohematopoietic progenitors in the human embryo. Blood 119:3712-3723, 2012.

7. Zambidis ET, Soon Park T, Yu W, et al. Expression of angiotensin-converting enzyme (CD143) identifies and regulates primitive hemangioblasts derived from human pluripotent stem cells. Blood 112: 3601-3614, 2008.

8. Goker H, Haznedaroglu IC, Beyazit Y, et al. Local umbilical cord blood renin-angiotensin system. Am Hematol 84: 277-281, 2005.

9. Koca E, Haznedaroglu IC, Acar K, et al. Renin-angiotensin system expression in the K562 human erythroleukaemic cell line. J Renin Angiotensin Aldosterone Syst 8:145-147, 2007.

10. Sayitoglu M, Haznedaroglu IC, Hatirnaz O, et al. Effects of Imatinib Mesylate on Renin-Angiotensin System (RAS) Activity During the Clinical Course of Chronic Myeloid Leukaemia. J Int Med Res 37: 1018-1028, 2009.

11. Uz B, Tatonyan SC, Sayitoglu M, et al. Local hematopoietic renin-angiotensin system in myeloid versus lymphoid hematological neoplastic disorders. J Renin Angiotensin Aldosterone Syst 2012 Nov 6. doi:10.1177/1470320312464677

12. Gomez RA, Norling LL, Wilfong N, et al. Leukocytes synthesize angiotensinogen. Hypertension 21: 470475, 1993.

13. Lin C, Datta V, Okwan-Duodu D, et al. Angiotensinconverting enzyme is required for normal myelopoiesis. FASEB J 25: 1145-1155, 2010.

14. Abali $\mathrm{H}$, Haznedaroglu IC, Goker $\mathrm{H}$, et al. Circulating and local bone marrow renin-angiotensin system in leukemic hematopoiesis: preliminary evidences. Hematology 7: 75-82, 2002.

15. Aksu S, Beyazit Y, Haznedaroglu IC, et al. Over-expression of angiotensin-converting enzyme (CD 143) on leukemic blasts as a clue for the activated local bone marrow RAS in AML. Leuk Lymphoma 47: 891-896, 2006.

16. Beyazit $\mathrm{Y}$, Aksu S, Haznedaroglu IC, et al. Overexpression of the local bone marrow renin-angiotensin system in acute myeloid leukemia. J Natl Med Assoc 99: 57-63, 2007.

17. Casares MTG, De la Iglesia S, Perera M, et al. Renin expression in hematological malignancies and its role in the regulation of hematopoiesis. Leuk Lymphoma 43: 2377-2381, 2002 
18. Inigo SDL, Casares MTG, Jorge CEL, et al. Relevance of renin expression by real-time PCR in acute myeloid leukemia. Leuk Lymphoma 47: 409-416, 2006.

19. Livak KJ, Schmittgen TD. Analysis of relative gene expression data using real-time quantitative PCR and the 2(-Delta Delta C(T)) Method. Methods 25: 402408, 2001.

20. Haznedaroglu IC, Savas MC, Benekli M. Renin-like activity in leukemic blast cells: an initial clue to a local renin-angiotensin system in the bone marrow. Ann Hematol 75: 69-70, 1997.

21. Marusic-Vrsalovic M, Dominis M, Jaksic B, Kusec R. Angiotensin I-converting enzyme is expressed by erythropoietic cells of normal and myeloproliferative bone marrow. Br J Haematol 123: 539-541, 2003.

22. Khodunova EE, Parovichnikova EN, Gal'tseva IV, et al. Dynamic study of Bcl-2, Bax, p53, and ACE expression in CD34+ cells of peripheral blood and bone marrow in acute leukemia patients in the course of induction chemotherapy. Ter Arkh 83:32-37, 2011.

23. Brunet dIG, Ivanovic Z, Leprivey-Lorgeot $\mathrm{V}$, Praloran $\mathrm{V}$. Angiotensin II that reduces the colony-forming ability of hematopoietic progenitors in serum free medium has an inverse effect in serum-supplemented medium. Stem Cells 20: 269-271, 2002.

24. Wulf GG, Jahns-Streubel G, Nobiling R, et al. Renin in acute myeloid leukaemia blasts. $\mathrm{Br} J$ Haematol 100: 335-337, 1998.

25. Wulf GG, Jahns-Streubel G, Strutz F, et al. Paraneoplastic hypokalemia in acute myeloid leukemia: A case of renin activity in AML blast cells. Ann Hematol 73: 139-141, 1996.
26. Inigo SD, Lopez-Jorge CE, Gomez-Casares MT, et al. Induction of apoptosis in leukemic cell lines treated with captopril, trandolapril and losartan: A new role in the treatment of leukaemia for these agents. Leuk Res 33: 810-816, 2009.

27. Takeda A, Goolsby C, Yaseen NR. NUP98-HOXA9 induces long-term proliferation and blocks differentiation of primary human CD34+ hematopoietic cells. Cancer Res 66: 6628-6637, 2006.

28. Yassin ER, Abdul-Nabi AM, Takeda A, Yaseen NR. Effects of the NUP98-DDX10 oncogene on primary human CD34+cells: role of a conserved helicase motif. Leukemia 24: 1001-1011, 2010.

\section{Correspondence}

Dr. Burak Uz

Sürsürü Mahallesi, İmam Efendi Bulvarı, Gökkuşağı Sitesi, Hüzzam Apt. Daire: 1 ELAZIĞ / TURKEY

Tel: (+90.506) 4298632

e-mail: burakuz78@gmail.com 